\title{
Local Wisdom, Hinduism, and Religious Education in the Present Day Indonesia: Challenge and Opportunity ${ }^{1}$
}

\author{
I Ketut Ardhana \\ Udayana University; Hindu University of Indonesia, Bali, Indonesia
}

\begin{abstract}
There have not been many studies on the relationship between local wisdom, Hinduism, and religious education in the present day Indonesia, though since the Indonesian Independence on August 17, 1945 it has been known that the freedom of beliefs based on the Pancasila ideology has been declared. It can be understood since the majority of the Indonesians are Muslim and there are only small proportions of the minority groups, including Christians, Catholics, Hinduism, Buddhism, and Confucianism. Indeed, for a long time, the existence of certain religion, particularly Hinduism has become a political debate. However, since more than a decade that was in 1959, Hinduism has been acknowledged as a formal religion. The question is: How can we consider that Hinduism has been practiced and has a proper place in the context of religious life in Indonesia? In order to be able to answer this question, this paper will focus on certain issues: Firstly how was Hinduism in the New Order regime being practised? Secondly, how is Hinduism in the Reformation period being practised? Thirdly what are challenges and opportunities to practice Hinduism in the democratic government? It is expected that these questions will be able to have a better understanding, especially on local wisdom, Hinduism, and religious education in the present day Indonesia.
\end{abstract}

Keywords: local wisdom, Hinduism, Pancasila, religious education and Bali Indonesia

\section{Introduction}

Though the majority of the Indonesians are Muslim, Indonesia is not an Islamic state. Since the Indonesian independence on August 1945, the freedom of beliefs has been announced, based on Pancasila. The ideology of Pancasila is taken from the roots of the Indonesian culture and the date of June 1, 1945 as the birth of the Pancasila as the five basic principles of the Indonesian archipelago. The Pancasila ideology consists of the belief in God, Humanity, Indonesian Integration, democracy, and social justice, which is expected to protect the Indonesians from colonialism, capitalism coming from the Western World that had colonialized the Indonesians since their arrival in the Indonesian archipelago. Though the Pancasila is considered to be the strong ideology, but it does not mean there are not certain resistances from any ideologies such as religious ideology, nationalism, and communism that need to be existed also in the archipelago. In the past, from the Indonesian historical notes, it shows that it is only the opposition between religious and nationalist ideologies

\footnotetext{
${ }^{1}$ Paper presented at the International Conference on Human Rights, Democracy and Human Dignity: 70 Years of Universal Declaration of Human Rights held by Himachal Pradesh National Law University and Grand Academic Portal on 9-10 November 2019 at Shimla, Himachal Pradesh India.

I Ketut Ardhana, Prof. Dr. (phil.) Postgraduate Program on Cultural Studies, Faculty of Arts Udayana University, the Vice Chancellor of the Widya Kerthi Foundation-Hindu University of Indonesia (Denpasar), Bali, Indonesia.
} 
emerged, since the communist ideology has been expelled out from the Indonesian archipelago since the last rebellion broke out in September 1965.

Despite of that, in the recent political development, it does not mean that there are not crucial issues regarding on the one hand, the fast development of globalization and modernization, based on their religious beliefs, and on the other hand there are some crucial issues regarding the impacts of the religious development that have reduced the practices of the local culture and local wisdom. This means that the religious development and other beliefs could be anticipated regarding the religious practices should be practiced in a good way, in which one to each to each other should be tolerant and appreciate in the context of balance and harmonious religious life (Yusuf, 2013).

This can be done in certain ways and one of the ways is through the best and smart education system.

It can be seen on how the ideological conflicts took place amongst the Islamic ideology, nationalism, and communism in the 1960s, though we can see that the roots of conflicts can be seen in the 1920s during the Dutch colonial era. It can be said that Islam has played indeed a major role against the Dutch colonial era in which we know certain significant Islamic parties such as Sarekat Islam (SI), Nahdlatul Ulama (NU), Majelis Syuro Muslimin Indonesia, or Masyumi to mention a few. In the 1960s due to the significant role of the Masyumi under the Islamic umbrella that it needs to establish an Islamic state (For a reference see: Ardhana, 2000).

Meanwhile, the NU and the Muhammadiyah are two of the Islamic organizations that cover the social and religious movement. Due to its significant role, especially the social and religious movements become a reason why these two Islamic organizations established until in the present day Indonesia.

This crucial issue regarding the ideas of Islamic state, the first President of Indonesia, Soekarno at that time had declared that the Masyumi is as an illegal political party any longer. However, it does not mean that there were no any efforts from the Islamic groups to continue their dreams to struggle through the political parties until at the present day Indonesia.

\section{Old Issues and New Faces}

In the context of the Hinduism the same conflicts also happened, due to the patron-client relationship between the Balinese upper class or the Triwangsa group presented by the Bali Adnyana against the Balinese lower class, presented by the Suryakanta or the Sudra group or the common people regarding the politics of primordialism took place as well. It can be understood since the modern Balinese do not want to have certain conflicts in terms of the caste system, but rather than in the modern democratic ways of thinking. Despite of that the conflicts already lasted since 1920s, in fact we still can witness the soft conflicts amongst them until at the present day Bali, particularly in the ritual and religious aspects.

As already mentioned above, the internal conflicts already happened in the Balinese society regarding the traditional and the modern movements. However, in the modern Balinese society certain conflicts also take place between the India or Indic influences, representing by the Hari Khrisma, the Sai Baba groups against the influences of the local Balinese culture or the Bali influences that already rooted in the context of the Balinese history. Through this concept, the local Balinese groups argue that though the Indic or Indian influences, the significant is how they can maintain and preserve their local culture and in other words it means that they will strongly empower their local wisdom based on the archeological and historical sites while practicing the Hindu religion in Bali in particular and in Indonesia in general. Through this new paradigm, the modern Balinese 
would manage many issues regarding the ritual and religious practices in the context of their daily life. It means also that the modern Balinese never avoid the external influences due to the development of modernization and globalization, rather than by adopting and adapting those external influences to strengthen their-own local culture.

From this description, it can be said that not only on the one side in the context of Islamic influences in Indonesia in general, but also in the context of India or Indic influences in the Balinese society in particular has created certain conflicts. In other words, it can be said also that the religious ideology is still used in the context of political negotiations and contestations. The significant issues are how the local government and community are capable in managing these conflicts in order to be able to live in sustainable ways in the context of a multicultural society. This is important to understand that since in the Indonesian independence, the religious life has been regulated based on the ideology of Pancasila that already rooted in the context of Indonesian history in such a long time until at the modern and postmodern Indonesia (Fasya, 2017).

During the New Order regime, the nationalist groups have defeated the communist groups and the religious groups. It is not surprising, why the religious groups had no chances to establish a strong organization in compared to the nationalist groups. Due to this social and political situation, it is not surprising why the religious groups such as we can see in the Islamic organization are still trying to empower the religious political ideology against the nationalist groups as we will elaborate more below.

\section{Religious Movement and Political Struggle in the Present Day Indonesia}

The ideology of Islamic syariah has been introduced since a long time of the Indonesian history. The ideology of syariah has not been practiced not only in terms of religious aspects, but also in terms of economic aspect, but under the umbrella of the Pancasila ideology which means unity and diversity. The ideology of Pancasila consists of first: believe in God, second: humanity, third: integration of Indonesia, fourth: democracy and fifth: social justice.

This can be understood that the Indonesian society is a multicultural society and not as a homogenous society. The most significant is in the context of education and youth groups such as Himpunan Mahasiswa Islam or HMI that emerged during the New Order era (1966-1998). This young Islamic organization has been established not only in Indonesia, but also in a broad. Later, the emergence of the Front Pembela Islamor (FPI) and lastly has been prohibited by the Indonesian government especially about Hizbul Tahir Indonesia or HTI, since this group has been considered as a dangerous group due to its role in the political demonstration (Aziz, 2017). There have been many discussions about these Islamic movements amongst the young Indonesians. While in other side, particularly in the Hindu groups to mention a few there have been also the Peradah or the Pemuda Hindu Indonesia to mention a few (Ardhana, 2019). The same case also takes place in the context of Christian youth groups and the Catholic youth groups.

The central government is really carefully to handle these issues, since much political unrest based on the Islamic religious ideologies. It is even that, some terrorist attacks are linked with certain Islamic organizations, though in reality it is not really true. This can be understood that there is no religion teach about the violence against the humanity. Discussions amongst these groups have become significant since in the Indonesian election for instance in 2019, the role of the Indonesian youth groups becomes significant to recruit political votes from the young generation who have their election votes. 


\section{The Significant of Education System: The Change of Educational Paradigm and the Pancasila}

There are some efforts that have been provided by the Indonesian government in order to be able to manage certain issues or conflicts regarding on how to maintain the existence of Pancasila as the basic principle of the Indonesian state that has been proclaimed since August 17, 1945. Though this has been a national commitment, in fact there have been on the one side, some significant issues related to the certain discourse like the Islamic state that have been proposed by certain Islamic organizations, in which they do hope struggling in the future. However, on the other side, they do hope that the Indonesian state based on the Pancasila is the final decision, decided by all of the Indonesians, since the proclaimed Indonesian state. Based on the latest development the majority of the Indonesians who have supported the nationalist ideology have realized that there is a need to maintain and preserve the Indonesian state.

From the historical evidences, it is noted that most of the Islamic Indonesian mazhab is the Syafii followers who are very tolerant with the local wisdoms that already rooted in such a long time of the Indonesian history. Since such a long time of the Indonesian history it has been well known that the Nahdlatul Ulama followers closely linked with the local genius, Indian and Indic influences. This can be understood since the Hinduism has already rooted in the Indonesian history, which is in Java particularly in East Java and Bali. In both two areas, the Hindu Javanese culture has already rooted in such a long time, in which there was a married between the Hindu Buddha Javanese princesses, Mahendradatta with the Balinese prince, Udayana in the 11th to the 12th century. This becomes one indicator on how the emergence of a multicultural society already beginns in the context of Javanese and the Balinese history. It is significant to note that during the two kings in Bali they were successfully to integrate two different religions between the Hindu and the Buddhism in the Samuan Tiga Temple-nowadays in the Gianyar regency, well known as Bhinneka Tunggal tan hana dharma mangrwa which means unity in diversity. Since at that time, it can be said that there were no conflicts any longer between the different groups of beliefs and religious differences.

Though the differences of two cultures between the Javanese and the Balinese, in fact both of two cultures already had the similar religious education system, based on the local culture in every community (Krishna, 2012). In such a long time, the religious education system has been established in Java called the pesantren and in Bali called the pasraman. The problems are that not all of the religious institutions have these kinds of community education system. In the Islamic institution, there is an Islamic foundation, called the pesantren and the pupils are well known as the santris. In Java, the teacher of pesantren called the Kyai, while in Bali the leader of pasraman called the guru. In Java, there have been many significant pesantren such the pesantren of Tebuireng and Gontor that produced talented and professional national figures.

Due to the significant role of these local institutions, it is not surprising if the central government in Jakarta makes use the role of those institutions to create the emergence of the young leader for the future. Based on this consideration, the Indonesian government has launched later the state regulation, called the Undang-Undang Pesantren. The state regulation regulates certain issues regarding the religious education system. In this new pasraman system it will be formatted namely $60 \%$ for the general subjects and the rest $40 \%$ the local subjects. The $60 \%$ subjects are linked to the social and natural sciences, and for the $40 \%$ subjects are linked to the local subjects such as religious and local cultures. 


\section{Conclusion}

Through this system, it is expected to be able to strengthen the ideology of Pancasila by strengthening certain subjects such as local wisdom, Pancasila, and the local culture. By stressing these subjects, it is expected that the young generation will be able to anticipate the negative influences of the foreign cultures, such as capitalism, liberalism, communism, and the like that are not based on the local culture in the Indonesian archipelago. In other words, it is expected that the young Indonesian generation will be able to compete with other nations, to reduce the impacts of radicalism and terrorism and to strengthen the ideas of togetherness and tolerance between one ethnic group to another ethnic group. By introducing this education system concept, it will be able to strengthen the ideology Pancasila in the context of the Indonesian sustainable development in general and the Balinese sustainable development in particular (Yoga Segara, 2017).

\section{References}

Asry, Y. (Ed.). (2013). Community build harmony: Conflict resolution and peace building in ethnoreligious Indonesia. Jakarta: Ministry of Religious Affairs, Republic of Indonesia, Office of Research and Developmental and Training-the Center of Research and Development of Religious Life.

Ardhana, I K. (2019). Towards modern Hinduism in Bali: A brief history of the Parisada Hindu Dharma Indonesia (PHDI). Denpasar: Larasan.

Ardhana, I K. (2000). Nusa Tenggara nach Einrichtung der Kolonialherschaft 1915 bis 1950. Passau-Germany: Lehrstuhl fur Sudoastaseinkunde-Universitat Passau.

Aziz, A. (2017). Intoleransi, Revitalisasi Tradisi dan Tantangan Kebinekaan Indonesia. Jakarta: The Ford Foundation and The Asia Foundation.

Fasya, T. K. (2017). Minoritas Agama dan Otoritas Negara. Jakarta: Puslitbang Agama dan Layanan Keagamaan Badan Litbang dan Diklat Kementerian Agama RI.

Krishna, A. (2012). Javanese Wisdom: Butir-butir Kebijakan Kuno Manusia Modern. Jakarta: Gramedia.

Yoga Segara, I N. (Ed.). (2017). Dimensi Tradisional dan Spiritual Agama Hindu. Jakarta: Puslitbang Binmas Agama dan Layanan Keagamaan Kementerian Agama RI. 